\title{
Osteoporosis therapies and their mechanisms of action (Review)
}

\author{
BEOMCHANG KIM ${ }^{1 *}$, YONG JIN CHO ${ }^{2 *}$ and WONBONG LIM ${ }^{1-3}$ \\ ${ }^{1}$ Laboratory of Orthopaedic Research, School of Medicine; Departments of ${ }^{2}$ Orthopaedic Surgery and \\ ${ }^{3}$ Premedical Sciences, College of Medicine, Chosun University, Gwangju 61452, Republic of Korea
}

Received June 1, 2021; Accepted August 4, 2021

DOI: $10.3892 / \mathrm{etm} .2021 .10815$

\begin{abstract}
Osteoporosis is a common disease that affects millions of patients worldwide and is most common in menopausal women. The main characteristics of osteoporosis are low bone density and increased risk of fractures due to deterioration of the bone architecture. Osteoporosis is a chronic disease that is difficult to treat; thus, investigations into novel effective therapeutic methods are required. A number of studies have focused on determining the most effective treatment options for this disease. There are several treatment options for osteoporosis that differ depending on the characteristics of the disease, and these include both well-established and newly developed drugs. The present review focuses on the various drugs available for osteoporosis, the associated mechanisms of action and the methods of administration.
\end{abstract}

\section{Contents}

1. Introduction

2. Consideration of targets in osteoporosis

3. Pharmacological therapy for osteoporosis

4. Conclusions

\section{Introduction}

Osteoporosis is a bone disorder in which the balance between bone resorption and bone formation is disrupted, resulting in an increase in bone resorption that decreases bone mineral density (BMD) (1). The World Health Organization (WHO) defines osteoporosis as a 'progressive systemic skeletal disease characterized by low bone mass and microarchitectural

Correspondence to: Professor Wonbong Lim, Department of Premedical Sciences, College of Medicine, Chosun University, 308 Philmundaero, Dong, Gwangju 61452, Republic of Korea

E-mail:wonbong@chosun.ac.kr

${ }^{*}$ Contributed equally

Key words: osteoporosis treatment, osteoblast, osteoclast, bone resorption, bone formation, bone remodeling, menopause, fracture deterioration of bone tissue, with a consequent increase in bone fragility and susceptibility to fracture' $(2,3)$. Osteoporosis is a common disease, affecting 200 million patients worldwide, and by 2020, an estimated 10-14 million individuals would be affected by osteoporosis in the USA $(1,4-6)$. Osteoporotic fractures can be alleviated by pharmacological treatment. Current osteoporosis treatments are either anti-resorptive, bone-forming or dual-acting (including both types of treatment) (5,7). Anti-resorptive drugs include bisphosphonates, anti-receptor activator of NF- $\mathrm{KB}$ (RANK) ligand (RANKL) antibodies (Denosumab), selective estrogen receptor modulators (SERMs) and calcitonin $(3,5,7)$. Bone-forming drugs include parathyroid hormone (PTH) and PTH-related protein (PTHrP) $(3,5,8)$. An example of a dual-acting drug is Romosozumab $(3,5)$. The present review highlighted the causes of osteoporosis and the mechanisms of action underlying the drugs used to treat this disease. In addition, the present study details an approach to drug development that has the ability to treat osteoporosis in a more effective manner.

\section{Consideration of targets in osteoporosis}

The WHO criteria for determining osteoporosis is a reduction in BMD of $\geq 2.5$ standard deviations (SD) below the average value for young healthy adults, as assessed via dual-energy X-ray absorptiometry (DXA) (9-14). This result is expressed as a $\mathrm{T}$-score, and a low $\mathrm{T}$-score $(<-2.5)$ is an indicator of osteoporosis $(12,13)$.

Osteoporosis is affected by several factors, including age and sex, and is divided accordingly into primary and secondary osteoporosis. Primary osteoporosis includes postmenopausal osteoporosis (type 1), which is characterized by a decreased production of estrogen that induces bone loss. On the other hand, secondary osteoporosis is caused by disease or drug exposure (type 2), and is characterized by reductions in bone function often due to malabsorption, glucocorticoid use, hyperparathyroidism, hypogonadism or excessive alcohol consumption $(3,9,10,15,16)$.

Risk factors. Osteoporosis is influenced by multiple factors. Representative causes and risk factors for osteoporosis include, but are not limited to, increasing age, post-menopause, hormones, genetics, ethnicity, calcium levels, body weight, exercise, poor nutrition, early menopause, lifestyle habits, chronic disease, rheumatoid arthritis, vitamin D deficiency, smoking and alcohol abuse (9,17-20). 
Diagnosis. Osteoporosis is a disease that has no major symptoms unless a fracture occurs $(9,17,21)$. However, it has previously been demonstrated that individuals aged $\geq 65$ years and postmenopausal women begin to lose bone density due to several risk factors, including low calcium uptake, smoking, alcohol abuse, certain medications and ethnic background. These risk factors are indicative for BMD measurements $(9,12,17,22)$. BMD T-scores are used for diagnosis, where T-scores >-1.0 SD denote normal bone mass; T-scores between -1.0 and -2.5 SD are defined as osteopenia; and T-scores $<-2.5 \mathrm{SD}$ are indicative of osteoporosis $(9,12,13,17,22)$.

Bone remodeling. Bone mass is maintained by continuous bone remodeling through bone formation by osteoblasts and bone resorption by osteoclasts (23-25). Bone remodeling is affected by growth factors, hormones and cytokines, which regulate osteoclast and osteoblast activity $(23,24)$. The regulation of osteoclast activity, differentiation and survival is critical in bone remodeling, whereby RANK, the corresponding ligand RANKL and decoy receptor osteoprotegerin (OPG) are key factors $(23,26,27)$.

Osteoclasts. Osteoclasts differentiate from hematopoietic stem cells, and are activated by macrophage colony-stimulating factor and RANKL to attach to bone and begin resorption $(3,28-30)$. Activated osteoclasts induce bone resorption through bone mineral dissolution and bone degradation via proteolytic enzymes and hydrochloric acid secretion (3,23,29,31-33). The main proteolytic enzymes released from osteoclasts are cathepsin K and MMP9 $(3,34,35)$. These enzymes are released in response to $\mathrm{PTH}$, and osteoclasts activated by PTH release bone minerals into the bloodstream $(3,24)$. Furthermore, the RANK-RANKL interaction activates additional signaling pathways, such as TNF-receptor associated factor 6 (TRAF6), MAPK, NF-кB, AKT, JNK and ERK, and increases the expression of genes associated with osteoclastogenesis $(3,23,24,28-30)$.

Osteoblasts. Osteoblasts differentiate from mesenchymal stem cells (MSCs), produce hydroxyapatite and enable bone formation through mineralized tissue formation (36-38). The mechanism of bone formation is classified into two types: Endochondral ossification and intramembranous ossification $(3,39)$. Endochondral ossification is an essential process for the formation and growth of long bones, healing of bone fractures and formation of cartilage by chondrocytes $(40,41)$, while intramembranous ossification is essential for rudimentary bone formation and bone fracture healing (42). Osteoblasts interact with signaling molecules, including Runt-related transcription factor 2 (Runx2), osterix, activating transcription factor 4 and the activator protein 1 family (3,43-45). In particular, Runx2 levels are increased by bone morphogenetic proteins (BMPs), Wnt levels, receptors for lipoprotein receptor-related protein 5 and 6 (LRP5/6) and frizzled (FZD)-related protein. Consequently, osteoblasts form and promote bone formation by synthesizing an extracellular matrix to maintain bone mass while inhibiting or increasing bone resorption $(3,46,47)$. Osteoblasts also produce RANKL, which promotes osteoclast differentiation, as previously described $(48,49)$.
Osteocytes. Osteocytes are the most common cells in mature bone. Unlike osteoclasts that survive for $\sim 12$ days and osteoblasts that survive for about 100 days, osteocytes live in the bone matrix $>10$ years (50-52). Osteocytes are derived from MSCs through osteoblast lineage differentiation and are the final differentiated form of osteoblasts that do not divide. Only 10-20\% of all osteoblasts differentiate into osteocytes. In mature bones, osteocytes are located in specific spaces called lacunae and canaliculi, and produce several proteins that affect bone remodeling (52-56). Osteocytes promote bone formation by releasing nitric oxide, prostaglandin E2 and ATP, and suppress bone formation by releasing sclerostin, Dickkopf-related protein 1 and FZD-related protein 1. In addition, osteocytes activate osteoclastogenesis by releasing RANKL. Sclerostin is expressed only in osteocytes, which acts as a ligand in the Wnt signaling pathway, activates canonical Wnt signaling, binds to LRP5/6 receptors and inhibits bone formation $(52,54,55,57,58)$.

$O P G$. OPG is a decoy receptor for RANKL and competes with RANK for binding to RANKL; therefore, OPG inhibits bone resorption by blocking the binding between RANK and RANKL. Furthermore, OPG serves as a decoy receptor for TNF-related apoptosis-inducing ligand (TRAIL), which induces osteoclastogenesis by increasing TRAF6 and NF- $\kappa \mathrm{B}$ signaling, and the expression of nuclear factor of activated T-cells cytoplasmic 1 (NFATc1) $(59,60)$.

Vitamin D. Vitamin D is a group of fat-soluble secosteroids that increase the intestinal absorption of calcium, magnesium and phosphate $(61,62)$. Vitamin D has two main forms: D2 (ergocalciferol) and D3 (cholecalciferol). D2 is extracted from plant sources and cannot be produced by humans, while D3 is mainly synthesized in the human skin and is ingested through animal foods, such as fish oil (63-66).

Vitamin D changes its structure several times during the digestion process, and finally becomes the activated form calcitriol, which enhances serum calcium levels by inhibiting parathyroid gene expression and parathyroid cell proliferation through binding to vitamin $D$ receptor (VDR) $(61,63,66)$. Calcitriol acts directly on three organ targets to maintain serum calcium levels $(61,62)$. The first target organ is the intestine, where calcitriol stimulates intestinal calcium absorption; the second is the kidneys, where calcitriol along with PTH encourages renal distal tubular reabsorption of calcium; and the third target is bone (61-66).

Calcitriol mobilizes calcium from the bone in a process that requires PTH. When calcium levels in serum decrease, PTH-dependent calcitriol activation occurs, promoting the formation and differentiation of osteoclasts (67-70). Activation of PTH-dependent calcitriol also induces the secretion of RANKL, which in turn induces the mobilization of calcium from the bone. Vitamin D activates this signaling pathway through VDR, and VDR signaling acts primarily on osteoblasts rather than osteoclasts, directly acting on the expression of RANKL, which is important for osteoclast production and increased bone resorption (71-73). Vitamin D also inhibits mineralization by increasing the levels of pyrophosphate and osteopontin. 


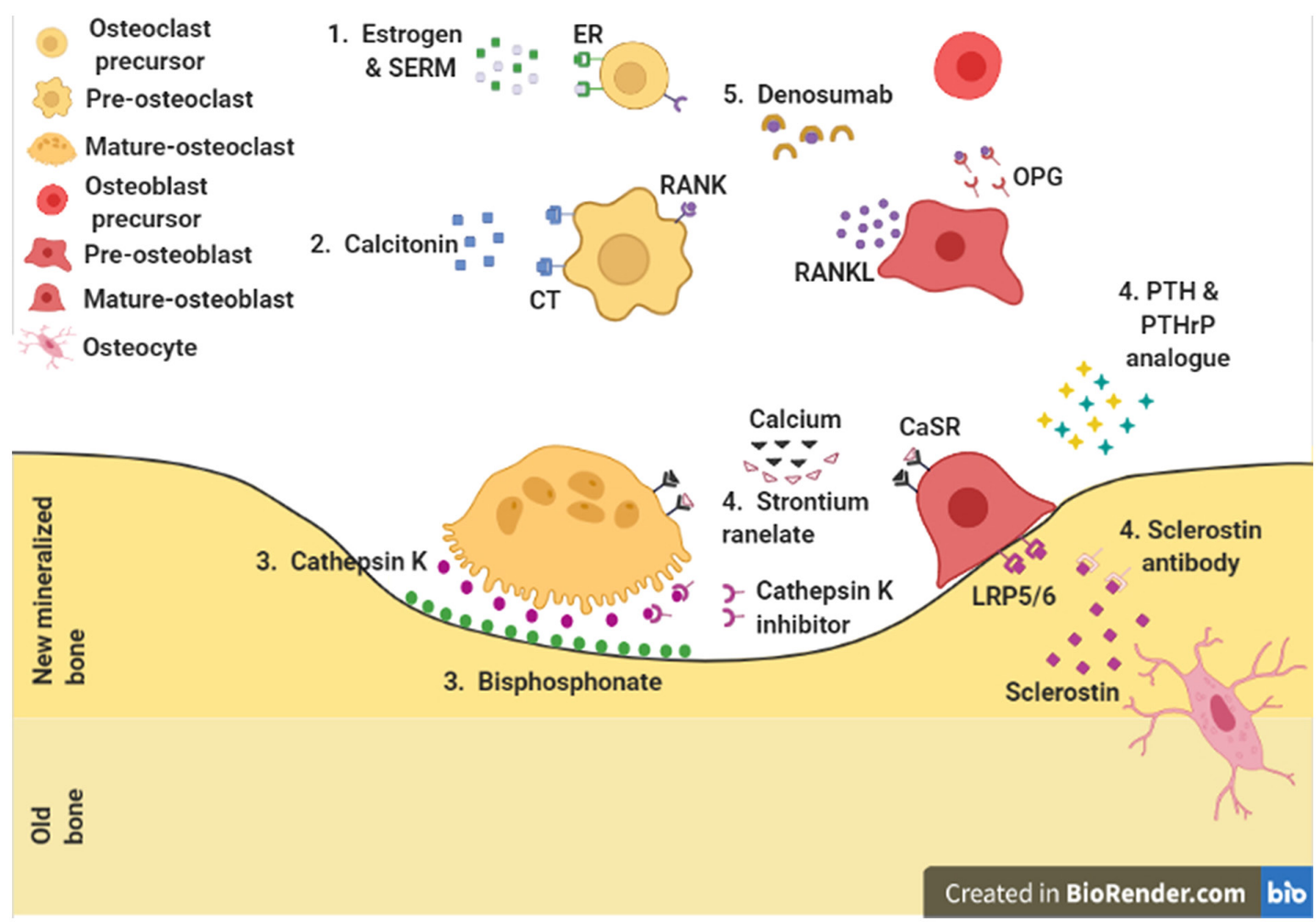

Figure 1. Pharmacological action sites for osteoporosis. 1. Pre-osteoclast: Estrogen and SERMs. 2. Osteoclast: Calcitonin. 3. Bone resorption site: Cathepsin K inhibitor and bisphosphonates. 4. Osteoblast: Strontium ranelate, PTH and PTHrP analogues, and anti-sclerostin antibody. 5. Osteoclast and osteoblast: Denosumab. ER, estrogen receptor; SERM, selective estrogen receptor modulator; CT, calcitonin receptor; RANK, receptor activator of nuclear factor- $\kappa \mathrm{B}$; RANKL, receptor activator of nuclear factor- $\kappa \mathrm{B}$ ligand; CaSR, calcium sensing receptor; LRP5/6, lipoprotein receptor-related protein 5 and 6; PTH, parathyroid hormone; PTHrP, PTH-related protein; OPG, osteoprotegerin.

\section{Pharmacological therapy for osteoporosis}

A number of drugs and therapeutic methods have been evaluated for the treatment of osteoporosis (Fig. 1). Since osteoporosis is caused by an imbalance between bone formation and bone resorption, drugs for treating osteoporosis have been developed accordingly (Table I). To initiate pharmacological treatment, the main purpose of which is to lower the risk of osteoporotic fractures, it is necessary to determine the patient's current condition and T-score and DXA are used as diagnostic techniques $(9,74-77)$.

\section{Anti-resorptive agents}

Bisphosphonates. Bisphosphonates are considered as the first-line pharmacological treatment for osteoporosis. There are several types of bisphosphonates, and their basic action is to attach to the bone and induce osteoclast apoptosis, thereby inhibiting bone resorption and increasing BMD (Table II) $(9,17,78,79)$. Bisphosphonates are stable analogs of pyrophosphate and have a P-C-P bond that provides binding affinity to hydroxyapatite. As osteoclasts begin to resorb bones covered with bisphosphonates, the released bisphosphonates reduce the ability of osteoclasts to form wrinkled boundaries and produce protons necessary for bone resorption $(3,17,80-85)$.

Bisphosphonates are classified into two types: Nitrogen-containing bisphosphonates (NBPs) and non-nitrogen-containing bisphosphonate (NNBPs; Table II) $(78,80,86)$. NBPs inhibit the farnesyl pyrophosphate synthase enzyme in the mevalonate pathway, which disrupts protein prenylation and causes cytoskeletal abnormalities in osteoclasts, resulting in the release of osteoclasts from the bone (78,80,87-89). Alendronate, risedronate, ibandronate, zoledronate, neridronate and pamidronate are typical NBPs $(78,80)$. As NNBPs do not contain nitrogen, they have a different mechanism of action compared with NBPs. NNBPs are exchanged for one half the ATP in terminal pyrophosphates and are metabolized after being incorporated intracellularly by osteoclasts. The metabolites, which act as ATP analogs, are then used instead of ATP and interfere with cell metabolism, consequently inducing osteoclast apoptosis $(78,80,86,87)$. Etidronate, clodronate and tiludronate are typical NNBPs (80). Regardless of the type, bisphosphonates have a central carbon atom, but the length and structure of the side chains vary. These differences determine their affinity for specific skeletal sites $(17,20,90,91)$. For example, alendronate has a high binding affinity to bone but is slow acting (91), while risedronate has a low binding affinity to bone and its effect appears rapidly due to its high diffusion ability $(20,90)$.

Bisphosphonates are administered as oral tablets or intravenous injections; oral tablets are preferred, but in case of adverse effects, intravenous injections are used instead. Common adverse effects of the oral administration of bisphosphonates are dysphagia, abdominal pain, nausea, flatulence, constipation or diarrhea, acid regurgitation, taste distortion, esophageal ulcers and gastritis $(9,17,92,93)$. Relatively rare adverse effects include atypical femoral fractures (AFFs), osteonecrosis of the jaw (ONJ), influenza-like symptoms, 
Table I. Summary of pharmacological drugs used for osteoporosis.

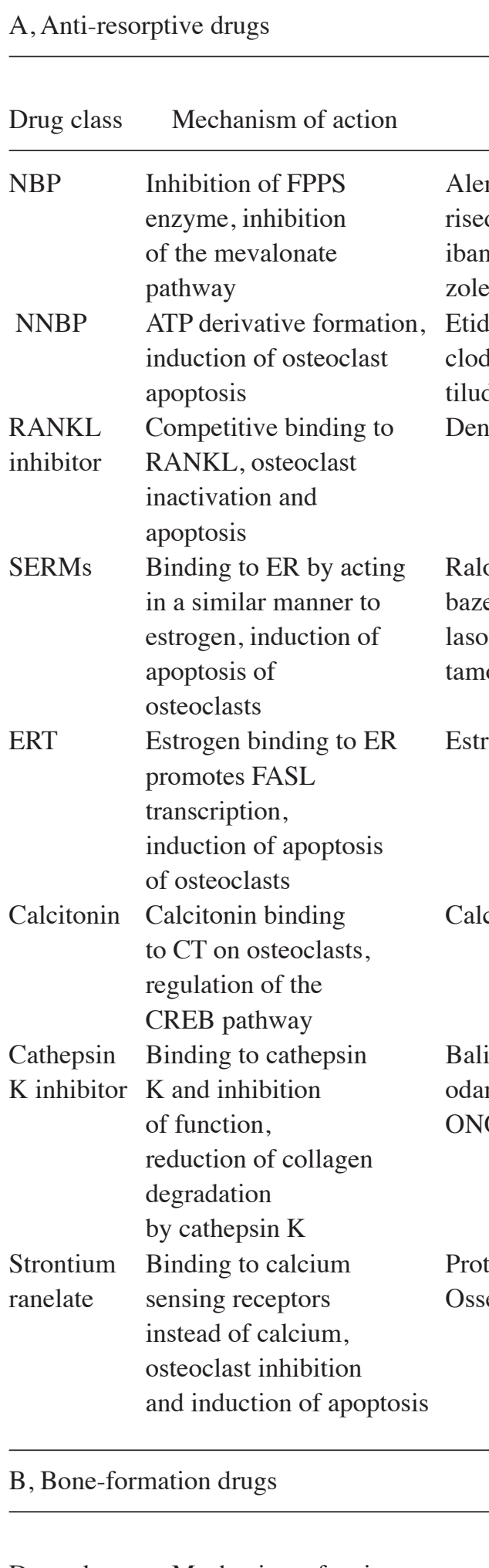

\begin{tabular}{|c|c|c|c|c|c|}
\hline Drug class & Mechanism of action & Name & $\begin{array}{c}\text { Method of } \\
\text { administration }\end{array}$ & Side effects & (Refs.) \\
\hline NBP & $\begin{array}{l}\text { Inhibition of FPPS } \\
\text { enzyme, inhibition } \\
\text { of the mevalonate } \\
\text { pathway }\end{array}$ & $\begin{array}{l}\text { Alendronate, } \\
\text { risedronate, } \\
\text { ibandronate, } \\
\text { zoledronate }\end{array}$ & Oral & $\begin{array}{l}\text { Dysphagia, nausea, } \\
\text { constipation/diarrhea, } \\
\text { gastritis, flatulence }\end{array}$ & $(9,17,79,81,93)$ \\
\hline NNBP & $\begin{array}{l}\text { ATP derivative formation, } \\
\text { induction of osteoclast } \\
\text { apoptosis }\end{array}$ & $\begin{array}{l}\text { Etidronate, } \\
\text { clodronate, } \\
\text { tiludronate }\end{array}$ & Oral, IV & $\begin{array}{l}\text { AFF, ONJ, acidregurgitation, } \\
\text { hypocalcemia, esophageal } \\
\text { ulcers }\end{array}$ & $(9,15,74,76,87)$ \\
\hline $\begin{array}{l}\text { RANKL } \\
\text { inhibitor }\end{array}$ & $\begin{array}{l}\text { Competitive binding to } \\
\text { RANKL, osteoclast } \\
\text { inactivation and } \\
\text { apoptosis }\end{array}$ & Denosumab & $\mathrm{SC}$ & $\begin{array}{l}\text { ONJ, AFF, musculoskeletal } \\
\text { pain, gastrointestinal } \\
\text { symptoms }\end{array}$ & $(17,29,50,93,102,103)$ \\
\hline SERMs & $\begin{array}{l}\text { Binding to ER by acting } \\
\text { in a similar manner to } \\
\text { estrogen, induction of } \\
\text { apoptosis of } \\
\text { osteoclasts }\end{array}$ & $\begin{array}{l}\text { Raloxifene, } \\
\text { bazedoxifene, } \\
\text { lasofoxifene, } \\
\text { tamoxifen }\end{array}$ & Oral & $\begin{array}{l}\text { Stroke, venous } \\
\text { thromboembolic disorder, } \\
\text { muscle cramps }\end{array}$ & $(17,102,109,110)$ \\
\hline ERT & $\begin{array}{l}\text { Estrogen binding to ER } \\
\text { promotes FASL } \\
\text { transcription, } \\
\text { induction of apoptosis } \\
\text { of osteoclasts }\end{array}$ & Estrogen & $\begin{array}{l}\text { Tablet, insert } \\
\text { pill, patch }\end{array}$ & $\begin{array}{l}\text { Breast cancer, heart disease, } \\
\text { stroke, venous } \\
\text { thromboembolic disorders }\end{array}$ & $(79,91,96,102,105)$ \\
\hline Calcitonin & $\begin{array}{l}\text { Calcitonin binding } \\
\text { to CT on osteoclasts, } \\
\text { regulation of the } \\
\text { CREB pathway }\end{array}$ & Calcitonin & $\begin{array}{l}\text { Oral, } \\
\text { intranasal spray }\end{array}$ & $\begin{array}{l}\text { Hypocalcemia, nasal adverse } \\
\text { reaction, anti-calcitonin } \\
\text { antibody formation, } \\
\text { prostate cancer }\end{array}$ & $(111-114)$ \\
\hline $\begin{array}{l}\text { Cathepsin } \\
\mathrm{K} \text { inhibitor }\end{array}$ & $\begin{array}{l}\text { Binding to cathepsin } \\
\mathrm{K} \text { and inhibition } \\
\text { of function, } \\
\text { reduction of collagen } \\
\text { degradation } \\
\text { by cathepsin } \mathrm{K}\end{array}$ & $\begin{array}{l}\text { Balicatib, } \\
\text { odanacatib, } \\
\text { ONO-5334 }\end{array}$ & Oral & AFF, stroke, pycnodysostosis & $(115-119,121,122)$ \\
\hline $\begin{array}{l}\text { Strontium } \\
\text { ranelate }\end{array}$ & $\begin{array}{l}\text { Binding to calcium } \\
\text { sensing receptors } \\
\text { instead of calcium, } \\
\text { osteoclast inhibition } \\
\text { and induction of apoptosis }\end{array}$ & $\begin{array}{l}\text { Protelos }^{\circledR}, \\
\text { Osseor }^{\circledR}\end{array}$ & Oral & $\begin{array}{l}\text { Cardiovascular disorder, } \\
\text { venous thromboembolic } \\
\text { disorder, myocardial } \\
\text { infarction }\end{array}$ & $(45,126,128,129)$ \\
\hline
\end{tabular}

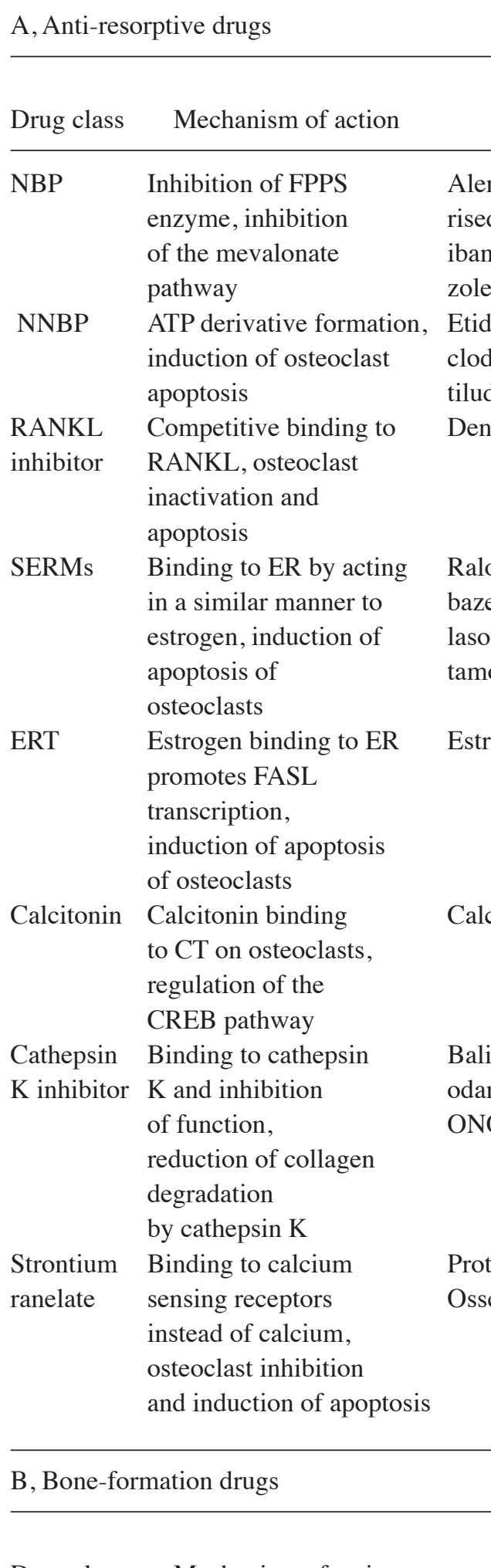

Method of

Drug class Mechanism of action Name administration 
Table I. Continued.

Dual-action drugs

\begin{tabular}{lllll}
\hline Drug class & Mechanism of action & Name & $\begin{array}{c}\text { Method of } \\
\text { administration }\end{array}$ & Side effects \\
\hline $\begin{array}{l}\text { Anti-sclerostin } \\
\text { antibody }\end{array}$ & $\begin{array}{l}\text { Degradation of sclerostin, } \\
\text { increased Wnt signaling }\end{array}$ & $\begin{array}{l}\text { Romosozumab, } \\
\text { blosozumab }\end{array}$ & SC, IV & $\begin{array}{l}\text { Stroke, cardiovascular } \\
\text { disorder, myocardial } \\
\text { infarction }\end{array}$ \\
$(163,164,166,167)$
\end{tabular}

NBP, nitrogen-containing bisphosphonate; FPPS, farnesyl pyrophosphate synthase; NNBP, non-nitrogen-containing bisphosphonate; IV, intravenous; AFF, atypical femoral fracture; ONJ, osteonecrosis of the jaw; RANKL, receptor activator of NF- $\mathrm{kB}$ ligand; SC, subcutaneous; SERM, selective estrogen receptor modulator; ER, estrogen receptor; ERT, estrogen replacement therapy; FASL, Fas ligand; CT, calcitonin receptor; CREB, cAMP-response element binding protein; PTH, parathyroid hormone; PTH1R, PTH-1 receptor; PTHrP, PTH-related protein.

hypocalcemia, uveitis and episcleritis $(9,17,92,94-96)$. The most common adverse effects associated with the stomach and digestion are alleviated by reducing the number of doses, or changing to intravenous administration or pre-prandial administration. Rare adverse effects are alleviated by reducing the dose or changing the time between doses, since bisphosphonates continue to be effective even if they are stopped after the first administration $(9,48,69-71)$. Despite common adverse effects, bisphosphonate is an ideal treatment option for patients with early osteoporosis if the administration method is followed up carefully $(1,9,74,97)$.

Denosumab. Denosumab is the first fully human monoclonal antibody that competitively binds to human RANKL, thus preventing the interaction between RANK and RANKL, and inhibiting the RANK/RANKL signaling pathway. Therefore, it inhibits osteoclast activity and differentiation, and consequently inhibits bone resorption, thus inhibiting osteoclast function $(3,17,28,49,92,98,99)$.

Denosumab is injected subcutaneously into the thigh or abdomen. Unlike bisphosphonates, it is not considered as a first-line treatment for osteoporosis. Denosumab is usually prescribed instead of bisphosphonates for patients with renal failure $(78,96)$. To confirm the efficacy of denosumab, a study was conducted called 'Fracture Reduction Evaluation of Denosumab in Osteoporosis every 6 Months' (FREEDOM), which revealed an increase in BMD and a decrease in bone turnover rate in the denosumab group compared with those in the placebo group $(5,17,100)$.

The FREEDOM study also highlighted the adverse effects of long-term denosumab treatment, which were similar to those associated with bisphosphonates, including ONJ, AFFs, hypocalcemia, musculoskeletal pain and gastrointestinal symptoms $(9,78,92,101)$. Unlike bisphosphonates, denosumab also weakens the immune system. As denosumab targets RANK-RANKL interactions, lymphocytes requiring RANK-RANKL interactions are affected, resulting in decreased lymphocyte activity and increased risk of infection $(92,101,102)$. Furthermore, unlike bisphosphonates, denosumab loses its efficacy rapidly after cessation of administration. If adverse effects occur, denosumab administration can be stopped immediately; however, the associated osteoporosis-suppressing effects also disappear rapidly $(78,98,102,103)$.

Estrogen replacement therapy (ERT). Estrogen is the primary sex hormone secreted by women, and estrogen secretion decreases as menopause begins. However, in osteoporosis, estrogen regulates osteoclast apoptosis. Estrogen binds to estrogen receptor $\alpha$, which translocates to the nucleus and binds the Fas ligand (FasL) transcription site to promote FasL transcription. FasL subsequently binds to Fas, a receptor present on the surface of pre-osteoclasts, inducing cleavage of caspase 8 and promoting osteoclast apoptosis $(78,101,104)$.

Hormone replacement therapy (HRT) is similar to ERT, but instead uses progestin in combination with estrogen. ERT or HRT is administered as tablets, patches on the skin or insertion of estrogen pills under the skin $(78,101,104)$. Long-term use of HRT and ERT exhibit adverse effects; HRT increases the risk of breast cancer, heart disease, stroke and venous thromboembolic disorders, while ERT increases the risk of endometrial cancer, stroke and venous thromboembolic disorders $(1,90,95,104-107)$. ERT is selectively used in menopausal women and is not considered a first-line therapy for osteoporosis. ERT or HRT should be discontinued upon adverse health effects; however, discontinuation increases the risk of osteoporosis $(78,101)$.

SERMs. SERMs are used to reduce adverse effects caused by the long-term use of estrogen. SERMs are nonsteroidal drugs that bind to estrogen receptors and exert selective estrogenic activity depending on the type of cell or tissue. SERMs function in a similar manner to estrogen, without any adverse effects on the breast or endometrium. Commonly used SERMs include raloxifene, bazedoxifene, lasofoxifene and tamoxifene $(78,101)$.

SERMs increase the risk of stroke, thromboembolic disorders and muscle cramps $(52,65,76)$. Thus, they are contraindicated for use in premenopausal women with osteoporosis, while they are considered a first-line therapy for postmenopausal women with osteoporosis $(78,101,108,109)$.

Calcitonin. Calcitonin is a 32-amino acid hormone secreted by thyroid $\mathrm{C}$ cells. The three main functions of calcitonin are: 
Table II. Classification of bisphosphonates.

\begin{tabular}{|c|c|c|c|c|}
\hline Drug name & $\begin{array}{l}\text { Molecular } \\
\text { formula }\end{array}$ & Indication & $\begin{array}{c}\text { Potency relative } \\
\text { to etidronate (Unit) }\end{array}$ & (Refs.) \\
\hline Alendronate & $\mathrm{C}_{4} \mathrm{H}_{13} \mathrm{NO}_{7} \mathrm{P}_{2}$ & $\begin{array}{l}\text { Paget's disease, osteoporosis in men and } \\
\text { postmenopausal women, glucocorticoid } \\
\text { induced osteoporosis }\end{array}$ & $100-1,000$ & $(90,176)$ \\
\hline Risedronate & $\mathrm{C}_{7} \mathrm{H}_{10} \mathrm{NNaO}_{7} \mathrm{P}_{2}$ & $\begin{array}{l}\text { Paget's disease, osteoporosis in men and } \\
\text { postmenopausal women, glucocorticoid } \\
\text { induced osteoporosis }\end{array}$ & $1,000-10,000$ & $(90,176)$ \\
\hline Ibandronate & $\mathrm{C}_{9} \mathrm{H}_{22} \mathrm{NNaO}_{7} \mathrm{P}_{2}$ & Osteoporosis in postmenopausal women & $1,000-10,000$ & $(90,176)$ \\
\hline Zoledronate & $\mathrm{C}_{5} \mathrm{H}_{10} \mathrm{~N}_{2} \mathrm{O}_{7} \mathrm{P}_{2}$ & $\begin{array}{l}\text { Paget's disease, osteoporosis in men and } \\
\text { postmenopausal women, glucocorticoid } \\
\text { induced osteoporosis }\end{array}$ & $>10,000$ & $(90,176)$ \\
\hline Neridronate & $\mathrm{C}_{6} \mathrm{H}_{16} \mathrm{NNaO}_{7} \mathrm{P}_{2}$ & $\begin{array}{l}\text { Paget's disease, osteogenesis imperfecta, } \\
\text { osteoporosis }\end{array}$ & 100 & $(90,176)$ \\
\hline Pamidronate & $\mathrm{C}_{3} \mathrm{H}_{9} \mathrm{NNa}_{2} \mathrm{O}_{7} \mathrm{P}_{2}$ & $\begin{array}{l}\text { Hypercalcemia of malignancy, Paget's } \\
\text { disease, osteolytic lesions of multiple } \\
\text { myeloma }\end{array}$ & 100 & $(90,176)$ \\
\hline
\end{tabular}

$\mathrm{B}, \mathrm{NNBPS}$

\begin{tabular}{|c|c|c|c|c|}
\hline Drug name & $\begin{array}{l}\text { Molecular } \\
\text { formula }\end{array}$ & Indication & $\begin{array}{l}\text { Relative potency } \\
\text { (Unit) }\end{array}$ & (Refs.) \\
\hline Etidronate & $\mathrm{C}_{2} \mathrm{H}_{8} \mathrm{O}_{7} \mathrm{P}_{2}$ & $\begin{array}{l}\text { Paget's disease, heterotopic ossification } \\
\text { following total hip replacement }\end{array}$ & 1 & $(81,176)$ \\
\hline Clodronate & $\mathrm{CH}_{4} \mathrm{Cl}_{2} \mathrm{O}_{6} \mathrm{P}_{2}$ & $\begin{array}{l}\text { Osteolytic bone metastases, hypercalcemia } \\
\text { of malignancy, transient osteoporosis of the hip }\end{array}$ & 10 & $(81,176)$ \\
\hline Tiludronate & $\mathrm{C}_{7} \mathrm{H}_{9} \mathrm{ClO}_{6} \mathrm{P}_{2} \mathrm{~S}$ & Paget's disease, osteoporosis & 10 & $(81,176)$ \\
\hline
\end{tabular}

NBP, nitrogen-containing bisphosphonate; NNBP, non-nitrogen-containing bisphosphonate.

i) To absorb calcium into the bones; ii) to inhibit calcium reuptake in the kidneys; and iii) to inhibit calcium reuptake in the small intestine. Thus, for osteoporosis treatment, calcitonin functions by storing calcium in bones. The majority of cells require calcium, which is necessary for multiple functions within cells. Among the different tissues that store calcium, bone stores the largest quantity of calcium by combining it with phosphoric acid to form hydroxyapatite (110-112).

The actions of calcitonin are opposite to those of PTH; PTH increases the concentration of blood calcium, whereas calcitonin decreases it $(111,112)$. Calcitonin binds to the calcitonin receptor on osteoclasts and regulates transcription through the cyclic adenosine monophosphate (cAMP)/protein kinase $\mathrm{A}(\mathrm{PKA})-\mathrm{cAMP}$-response element binding protein pathway (110-112).

Methods for calcitonin administration include injection, oral formulation and intranasal spray. Two types of calcitonin are used in therapy: Human and salmon calcitonin. Salmon calcitonin is used more often due to its high affinity for human calcitonin receptors. Calcitonin treatment is usually considered a second-line therapy for osteoporosis, and it is used when first-line therapy is ineffective or intolerable $(78,101,113)$. Calcitonin also exhibits adverse effects, such as hypocalcemia, nasal adverse reactions, formation of calcitonin antibodies and prostate cancer $(9,101)$. If adverse effects appear following the use of calcitonin treatment, it must be replaced with alternate osteoporosis therapies.

Cathepsin $K$ inhibitors. Cathepsin $\mathrm{K}$ is a member of the papain-like cysteine protease family and is highly expressed in osteoclasts. When osteoclasts are activated, cathepsin $\mathrm{K}$, residing in the lysosomes of osteoclasts, is released into the resorption lacuna, initiating bone resorption $(114,115)$. During bone resorption, osteoclasts form a structure called the sealing zone, which is a dynamic actin-rich structure that defines the resorption region. Subsequently, osteoclasts secrete several molecules, including proteases, to break down bone material for resorption (114-116). The bones are composed of a mineralized organic matrix consisting of $30 \%$ organic components and $70 \%$ inorganic components. The majority 
of organic components are composed of type 1 collagen, while the inorganic components are mainly composed of hydroxyapatite $(114,115,117)$. There are two types of collagen, types 1 and 2, which form a triple helix structure with two $\alpha 1$ chains and one $\alpha 2$ chain. Due to this structure, collagen resists proteolysis by proteases, such as MMP9 and serine protease. By contrast, cathepsin $\mathrm{K}$ efficiently cleaves collagen and any telopeptides to form collagen monomers (114,115,117-119), thus being an important marker of bone resorption and an ideal therapeutic target. When cathepsin $\mathrm{K}$ is inhibited, bone resorption activity of osteoclasts is suppressed, resulting in increased BMD (114-117).

Cathepsin $\mathrm{K}$ inhibitors include balicatib, odanacatib and 2H-Pyran-4-propanoic acid (114,119-121), which are administered orally. Unlike other bone resorption inhibitors, they inhibit the activity of osteoclasts, rather than reducing the number. Cathepsin $\mathrm{K}$ inhibitors are good anti-resorptive agents, but the associated adverse health effects are yet to be fully established. Reported adverse effects include increased risk of stroke, AFF and pycnodysostosis $(114,118,121,122)$. The stability of cathepsin $\mathrm{K}$ inhibitors is also yet to be elucidated; therefore, further studies on the adverse effects and stability of cathepsin K inhibitors are required $(101,118,120,123,124)$.

Strontium ranelate. Osteoblasts and osteoclasts have calcium sensing receptors (CaSRs), and their activity changes based on extracellular calcium concentration. Calcium activates various cellular pathways $(40,44,125)$. In osteoblastic cells, elevated extracellular calcium levels activate signaling pathways, including phospholipase C (PLC), protein kinase C (PKC), ERK, JNK, cAMP and PKA $(3,29)$. The ERK pathway increases the proliferation of osteoblastic cells, while the AKT pathway inhibits the apoptosis of osteoblastic cells by increasing survival signals $(3,29)$. Additionally, calcium increases the expression of insulin-like growth factor (IGF)-1 and IGF-2, thereby increasing the proliferation of osteoblastic cells and inducing differentiation by increasing the expression of cyclooxygenase 2 and prostaglandin E2 (125,126). In osteoclasts, when CaSR is activated by high levels of extracellular calcium, PLC and NF- $\kappa \mathrm{B}$ are activated, thus inducing the apoptosis of osteoclasts $(125,126)$.

Strontium, with an atomic number of 38 , is located just below calcium on the periodic table $(127,128)$. The nucleus of strontium is approximately the same size as that of calcium; thus, cells absorb strontium instead of calcium and transport it to bone or tooth enamel $(127,128)$. Although the mechanism of action of strontium ranelate has not been clearly identified, the characteristics of strontium and the reported research $(127,128)$ suggest that it enters the cell through CaSRs of osteoclasts and osteoblasts, and acts in a similar manner to calcium $(125,127,128)$. Therefore, strontium ranelate increases the differentiation and proliferation of osteoblasts, and the activated osteoblasts produce OPG, which reduces the activity of osteoclasts. Furthermore, it acts directly on the CaSRs of osteoclasts and increase their apoptosis $(125,127,129)$.

Strontium ranelate is administered orally. Due to its adverse effects, strontium ranelate is considered a second-line therapy, and is administered when other osteoporosis therapies cannot be used or are ineffective $(78,101)$. Common adverse effects include cardiovascular disorders, venous thromboembolism, myocardial infarction and symptoms of the nervous system. Rarely reported adverse effects include allergic reactions, such as drug rash with eosinophilia and systemic symptoms syndrome. Adverse effects associated with the heart are particularly severe. Therefore, it is recommended that strontium ranelate is administered only to patients with severe osteoporosis. It is not recommended for patients with severe renal impairment, thrombophlebitis, ischemic heart disease, a history of peripheral artery disease, cerebrovascular disease or hypertension $(101,128,130-132)$.

Mutant RANKL. Mutations within the TNF-like core domain of RANKL have been reported for creating a novel therapy for osteoporosis. The identification of RANKL as the final effector in the pathogenesis of osteoporosis has led to an improved understanding of bone remodeling. When RANKL binds to its receptor (RANK), osteoclastic differentiation and activation are initiated. RANKL is a member of TNF superfamily, which is a group of cytokines involved in cell proliferation and cell death consisting of 19 multimeric ligands interacting with cognate receptor molecules, the majority of which require trimerization to initiate their signaling cascade (133). Ligands belonging to the TNF superfamily are mostly type II transmembrane glycoproteins, containing a C-terminal, receptor-interacting ectodomain, a transmembrane domain and an N-terminal intracellular tail. The extracellular domain is either cleaved by the proteolytic activity of metalloproteases or produced by alternative splicing (133). Three-dimensional structures of TNF- $\alpha$, TRAIL and RANKL (alone and in complex with their respective receptors) have revealed remarkably similar overall structures that comprise unique conserved elements involved in receptor binding (134). Ko et al (135) and Jang et al (136) proposed a strategy using a RANKL variant as a competitive inhibitor for RANKL/RANK signaling. They suggest that this RANKL variant activates leucine rich repeat containing $G$ protein-coupled receptor 4 (LGR4) signaling, which competitively regulates RANK and acts as an immunogen that induces anti-RANKL antibody production, demonstrating a strategy in the development of general immunotherapy. The RANKL variant did not bind RANK in osteoclast progenitor cells, but activated LGR4 through the GSK3- $\beta$ signaling pathway, thereby suppressing the expression and activity of activated $\mathrm{T}$ cell cytoplasmic NFATc1 during osteoclastogenesis (Fig. 2). The aforementioned RANKL variant generated high levels of RANKL-specific antibodies, blocked osteoclastogenesis and inhibited osteoporosis in ovariectomized mouse models. Generated anti-RANKL antibodies demonstrated a high inhibitory effect on osteoclastogenesis in vivo and in vitro. In addition, Liu et al (137) demonstrated that immunization with a RANKL mutant generates an inter-species anti-RANKL antibody, which blocks the interaction between RANKL and its receptor, and further prevents the formation of osteoclasts and improves the bone density in rats with ovariectomy (OVX). Furthermore, the development of an unnatural amino acid into a RANKL vaccine has been proposed as a therapeutic approach to inhibit RANKL activity (138). An anti-RANKL vaccine, $\mathrm{Y} 234 \mathrm{pNO}_{2}$ Phe, was constructed by substituting a single tyrosine residue (Tyr234) in murine RANKL with p-nitrophenylalanine ( $\left.\mathrm{pNO}_{2} \mathrm{Phe}\right)$, and it was demonstrated that $\mathrm{Y} 234 \mathrm{pNO}_{2} \mathrm{Phe}$ induced a high titer antibody response 


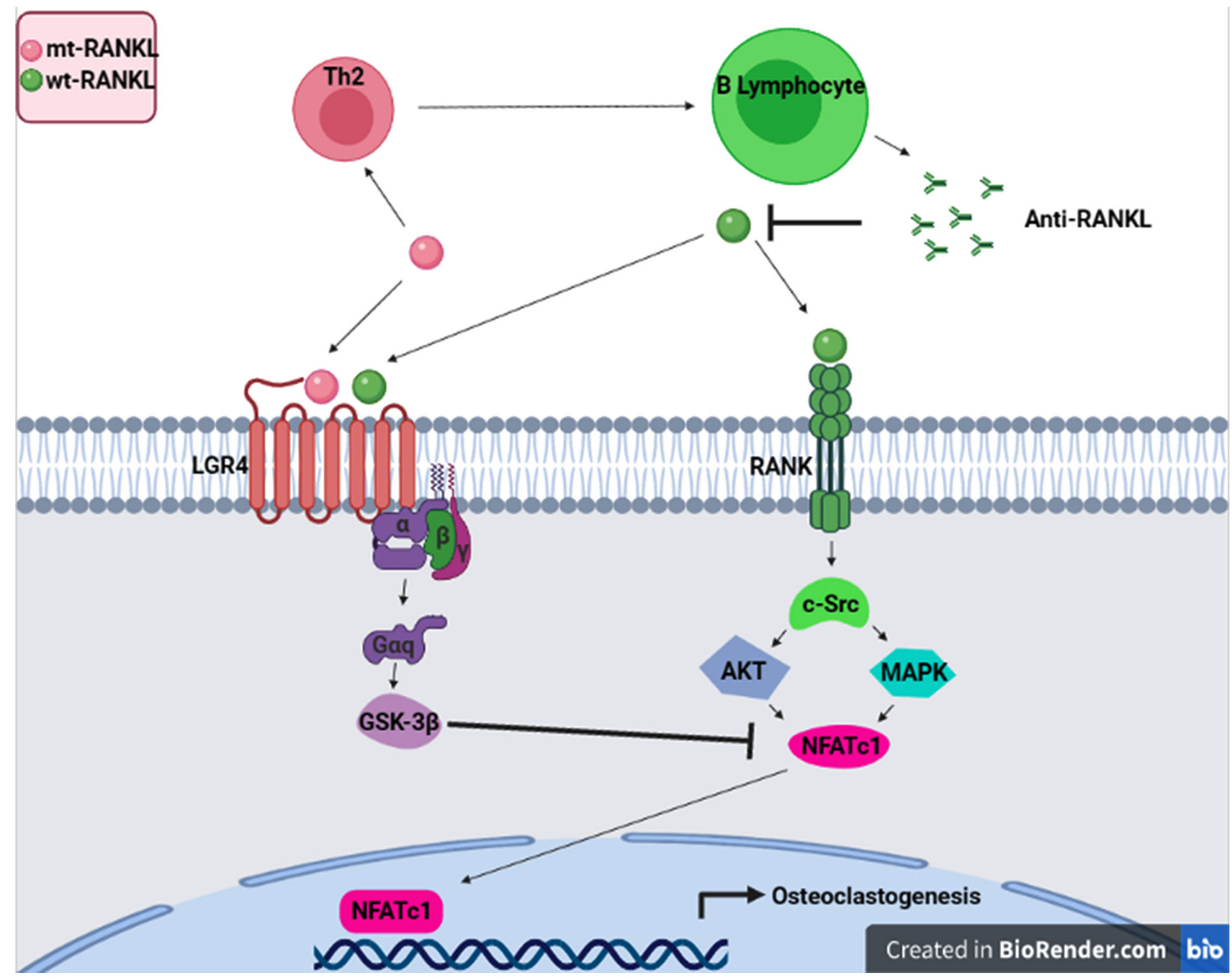

Figure 2. Schematic diagram of mutant RANKL and inhibitory effect against RANKL during osteoclastogenesis. RANK, receptor activator of nuclear factor- $\mathrm{kB}$; RANKL, receptor activator of nuclear factor- $\mathrm{B}$ ligand; LGR4, leucine rich repeat containing G protein-coupled receptor 4; mt, mutant; wt, wild-type; NFATc1, nuclear factor of activated T-cells cytoplasmic 1.

in C57BL/6 mice and prevented OVX-induced bone loss in mice (138). The potential advantage of a vaccine-type approach to RANKL inhibition compared with that of antibody-based approaches is that patients who discontinue denosumab experience rapid increases in bone remodeling and an increased risk of multiple vertebral fractures. It is possible, although not clearly demonstrated, that this vaccine approach may not induce rapid high-turnover bone loss, either by causing more durable RANKL inhibition or by allowing a more gradual resumption of remodeling when vaccinations are discontinued. It would be reasonable to evaluate this vaccine approach for its ability to minimize the risk of high-turnover bone loss in situations where vaccinations and boosters are discontinued.

Non-coding RNA. Long non-coding RNAs (lncRNAs) represent a group of non-protein-coding RNA transcripts that have been reported to play pivotal roles in various biological functions such as gene expression, cell proliferation and differentiation (139). As a 'bridge' between DNA and protein, RNA serves a complex regulatory role. In eukaryotic cells, protein-coding RNA (mRNA) only accounts for $\sim 2 \%$ of the genome, and the remaining transcripts are categorized as non-protein-coding RNAs (133). Unlike ribosomal RNA and transfer RNA, which are well known, other non-coding RNAs were previously considered to be transcriptional 'noise' (140). However, a recent study by Zhu et al (141) revealed that lncRNAs serve a vital role in regulating bone and cartilage development and remodeling processes. Research on microRNAs (miRNAs/miRs) and lncRNAs in the context of osteoporosis is limited. Often, there are conflicting results in the literature, such as miR-223 having the ability to both promote and inhibit osteoclastogenesis. Wijnen et al (142) suggested that miRNAs provided both positive and negative cross-talk between different regulatory pathways, thereby leading to the aforementioned phenomenon. Another potential explanation is that miRNA is present in different clinical specimens. For example, Mandourah et al (143) found that while both miR-122-5p and miR-4516 were suitable biomarkers for osteoporosis, miR-122-5p was detectable in serum, while miR-4516 was found in plasma (143). A large cohort study of 682 women found that there was no association between bone parameters and circulating levels of miRNAs, although these results changed after age adjustment. The authors suggested that this observation could be due to the fact that age was also strongly associated with the serum levels of the 32 miRNAs they selected. These factors may be associated with fragility fracture and low BMD in patients with osteoporosis, and may provide new insights into the modulation and potential treatment of osteoporosis.

\section{Bone formation therapies}

PTH analogue. PTH is an 84-amino acid peptide hormone that is synthesized in the parathyroid glands and regulates serum calcium concentration. PTH function is mediated by PTH-1 
receptor (PTH1R), which is a $\mathrm{G}$ protein-coupled receptor (GPCR) expressed in osteoblasts and oocytes (144-146). When PTH1R is stimulated, it activates several GPCR-related signaling pathways, such as the cAMP/PKA, PLC/PKC and ERK signaling pathways. Furthermore, PTH regulates the Wnt signaling pathway by downregulating sclerostin, a Wnt antagonist (145-149). The effects of PTH are divided into anabolic and catabolic effects. The anabolic effect of PTH increases the differentiation and growth of osteoblasts, thereby increasing bone formation, while its catabolic effect increases bone resorption indirectly, since osteoclasts are activated by RANKL secreted by osteoblasts (146-148).

PTH analogues are administered in a continuous or intermittent manner. When a PTH analogue is administered, markers of bone formation are initially increased, and those of bone resorption are activated at a later point; the period in which bone formation is higher than bone resorption is called the anabolic window, during which maximum bone formation occurs. After the anabolic window period, bone resorption gradually increases (150-152). PTH analogues are not recommended as first-line therapy for osteoporosis due to their high cost and difficulty of administration by subcutaneous injections. Adverse effects of PTH analogues include dizziness, headache, nausea and leg cramps. In addition, in animal experiments, osteosarcoma was reported to be induced based on the duration of the treatment; therefore, the administration of PTH analogues should be limited to 2 years (153-155).

PTHrP analogue. PTHrP, a member of the PTH family, is secreted by MSCs. PTH and PTHrP share 8 of the first 13 amino acids, have similar secondary structures, an overall homologous sequence and bind to the same receptor $(147,156,157)$. PTH1R has two conformations: i) $\mathrm{G}$ protein-dependent $\mathrm{RG}$ conformation; and ii) a $\mathrm{G}$ protein-independent $\mathrm{R} 0$ conformation. The two conformations activate the same signaling pathway, yet demonstrate different response patterns depending on the activated conformation (158-160). Long-lasting signaling was observed when the R0 conformation was activated, whereas short-lasting signaling was observed when the RG conformation was activated. Since anabolic and catabolic effects are activated as a long-acting signal in the R0 conformation, the anabolic effect is low; whereas in the case of the RG conformation, the anabolic effect is high with a strong signal that lasts for a short time. The binding affinities of the ligands for these two conformations are different. PTHrP analogues have a higher affinity for the RG conformation than that of PTH analogues. Thus, PTHrP analogues are expected to exert an improved anabolic effect than that of PTH analogues (144,147,159-161).

The adverse effects of PTHrP analogues are similar to those of PTH analogues, including gastrointestinal complaints, injection-site reactions, dizziness and myalgia. Furthermore, a mouse model demonstrated that PTHrP analogs were associated with osteosarcoma and osteoblastoma, similarly to the observations with PTH analogues. Thus, PTHrP analogue administration is limited to 2 years $(153-155,158)$.

\section{Dual-action therapy}

Anti-sclerostin antibody. Sclerostin is a glycoprotein secreted by osteocytes; it functions as an antagonist of BMP and suppresses the canonical Wnt signaling pathway. Sclerostin interacts with pro-BMP7 and mature BMP7 to increase the intracellular accumulation of BMP7, leading to its degradation. Thus, sclerostin inhibits the BMP7 signaling pathway $(162,163)$. The canonical Wnt signaling pathway is activated by the binding of a Wnt ligand to a receptor complex composed of LRP5/6 and FZD receptors. FZD mediates the recruitment of axin to form a complex that inhibits $\beta$-catenin phosphorylation by GSK-3 $\beta$. Non-phosphorylated $\beta$-catenin then accumulates in the cytoplasm, resulting in its nuclear translocation, and thereby triggers the transcription of genes involved in bone formation. It also induces the internalization of LRP5/6, which forms a complex with axin and adenomatous polyposis coli protein, which then degrades phosphorylated $\beta$-catenin (144,162-164). Anti-sclerostin antibody treatment removes sclerostin from the Wnt signaling pathway, thus activating the canonical Wnt signaling pathway, and consequently promoting bone formation and inhibiting bone resorption. $\beta$-catenin inhibits osteoclastogenesis by increasing the production of OPG in osteoblasts and by regulating the RANK/RANKL/OPG signaling pathway. Therefore, activation of the canonical Wnt signaling pathway not only increases bone formation but also decreases bone resorption $(144,162,164)$.

Anti-sclerostin antibody treatment is administered via subcutaneous injection, and the most common adverse effects are stroke, cardiovascular events and myocardial infarction. Furthermore, Wnt signaling is associated with cancer, which has been reported as an adverse effect in the Fracture Study in Postmenopausal Women with Osteoporosis (FRAME) study (144). Long-term anti-sclerostin antibody treatment, therefore, is not recommended, since it poses a high risk to the heart and may cause cancer $(144,165,166)$.

Combination therapy. Since pharmacological therapies for osteoporosis have limitations, several studies have been conducted to determine more effective therapies. An example of which is combination therapy, which is expected to exert a synergistic effect by using either two anti-resorptive drugs or an anti-resorptive drug with an anabolic drug.

In several studies, combination therapy was evaluated using existing drugs. The PTH and alendronate study used a combination of PTH and alendronate, and demonstrated no increase in BMD compared with that of the individual use of PTH or alendronate. Another study used a combination of PTH and SERMs, and also demonstrated no increase in BMD. By contrast, a combination of denosumab and teriparatide slightly increased BMD $(76,101,167-169)$. Another study reported that teriparatide can be used alone or in combination with denosumab and abaloparatide (170). Previous studies have indicated that PTH and PTHrP-related protein analogues, whether as monotherapy, in combination or in sequence with anti-resorptive agents, serve an important role in the management of osteoporosis (170). Since the benefit of combination therapy is only a slight increase in BMD, it is generally not recommended for osteoporosis due to its combined adverse effects and increased cost. Therefore, combination therapy is limited to patients with high risk of fractures or when other therapies are ineffective.

Sequential therapy. Since combination therapies are associated with more adverse effects than clear advantages, studies 
to identify other effective therapies, such as sequential therapy, have been conducted. Sequential therapy has been used to overcome the limitation of prolonged treatment time, which is a common problem with osteoporosis drugs.

In the denosumab and teriparatide transitions in postmenopausal osteoporosis (DATA-Switch) study, BMD increased in the spine and hips upon switching to denosumab after teriparatide treatment $(100,171)$. In the Abaloparatide Comparator Trial in Vertebral Endpoints study, switching from abaloparatide to alendronate increased BMD and maintained lowered fracture risk $(165,171,172)$. In the FRAME study, switching from romosozumab to denosumab also maintained a lower fracture risk. In an active-controlled fracture study in postmenopausal women with high risk of osteoporosis, switching from romosozumab to alendronate increased BMD and decreased non-vertebral fracture risk (171-175). As demonstrated in a number of studies, sequential therapy is effective against osteoporosis as it increases BMD compared with the effects of single sustained therapy. However, it has adverse effects, most of which appear to be similar to that of single therapies.

\section{Conclusions}

Osteoporosis, a chronic and difficult-to-cure disease, occurs naturally with age. As the lifespan of a person increases, so does the incidence of osteoporosis and the length of disease $(1,9)$. Therefore, effective long-term treatment options for osteoporosis are required. Among the various treatments for osteoporosis that are currently in use, pharmacological therapy is the most efficient and accessible, and has been rigorously studied $(9,10)$. Currently used therapies include those that inhibit bone resorption, promote bone formation and dual-action therapies $(9,17)$. Pharmacological therapies are used in patients with osteoporosis to reduce the risk of fracture and increase BMD, but their use is limited by adverse effects, which are determined by multiple factors, including the patient's nutritional status, genetic factors and past medical history $(7-9,13,17)$. To reduce these adverse effects, studies on individual variability, such as treatment time, concentration and timing of the administration of drugs, as well as drugs' mechanisms of action, such as osteoclast inhibition and osteoblast growth promotion, have been conducted $(13,17,20)$. In addition to single therapies with drugs, combination therapy and sequential therapy are under investigation to treat osteoporosis more effectively. However, it is not yet possible to completely cure osteoporosis, and there are serious adverse effects develop due to the long-term use of the current drugs. Therefore, there is a need to develop novel drugs that have the ability to effectively treat osteoporosis while minimizing adverse effects, regardless of variable patient-related factors.

\section{Acknowledgements}

Not applicable.

\section{Funding}

The present study was supported by the Basic Science Research Program through the National Research Foundation of Korea (NRF), funded by the Ministry of Education in Korea (grant nos. NRF-2021R1I1A3046499, NRF-2021R1I1A1A010 49248 and NRF-2019R1G1A1100099).

\section{Availability of data and materials}

Not applicable.

\section{Authors' contributions}

BK, YJC and WL were responsible for project conceptualization. BK and YJC were responsible for writing and original draft preparation:. WL was responsible for writing, reviewing and editing the manuscript, and creating the figures. BK and YJC were responsible for the assessment of all the raw data. WL was responsible for project supervision and administration. BK, YJC and WL were responsible for funding acquisition. Data authentication is not applicable. All authors have read and approved the final manuscript.

\section{Ethics approval and consent to participate}

Not applicable.

\section{Patient consent for publication}

Not applicable.

\section{Competing interests}

The authors declare that they have no competing interests.

\section{References}

1. Tu KN, Lie JD, Wan CKV, Cameron M, Austel AG, Nguyen JK, Van K and Hyun D: Osteoporosis: A review of treatment options. P T 43: 92-104, 2018.

2. Genant HK, Cooper C, Poor G, Reid I, Ehrlich G, Kanis J, Nordin BE, Barrett-Connor E, Black D, Bonjour JP, et al: Interim report and recommendations of the World Health Organization task-force for osteoporosis. Osteoporosis Int 10: 259-264, 1999.

3. Noh JY, Yang Y and Jung H: Molecular mechanisms and emerging therapeutics for osteoporosis. Int J Mol Sci 21: 7623 , 2020.

4. Wright NC, Looker AC, Saag KG, Curtis JR, Delzell ES Randall S and Dawson-Hughes B: The recent prevalence of osteoporosis and low bone mass in the United States based on bone mineral density at the femoral neck or lumbar spine. J Bone Miner Res 29: 2520-2526, 2014.

5. Langdahl BL: Overview of treatment approaches to osteoporosis. Br J Pharmacol 178: 1891-1906, 2021.

6. Burge R, Dawson-Hughes B, Solomon DH, Wong JB, King A and Tosteson A: Incidence and economic burden of osteoporosis-related fractures in the United States, 2005-2025. J Bone Miner Res 22: 465-475, 2007.

7. Langdahl BL and Harsløf T: Medical treatment of osteoporotic vertebral fractures. Ther Adv Musculoskelet Dis 3: 17-29, 2011.

8. Camacho PM, Petak SM, Binkley N, Clarke BL, Harris ST, Hurley DL, Kleerekoper M, Lewiecki EM, Miller PD, Narula HS, et al: American association of clinical endocrinologists and American college of endocrinology clinical practice guidelines for the diagnosis and treatment of postmenopausal osteoporosis-2016. Endocr Pract 22 (Suppl 4): S1-S42, 2016.

9. Akkawi I and Zmerly H: Osteoporosis: Current concepts. Joints 6: 122-127, 2018.

10. De Martinis M, Sirufo MM and Ginaldi L: Osteoporosis: Current and emerging therapies targeted to immunological checkpoints. Curr Med Chem 27: 6356-6372, 2020.

11. Milat F and Ebeling PR: Osteoporosis treatment: A missed opportunity. Med J Aust 205: 185-190, 2016. 
12. Cosman F, de Beur SJ, LeBoff MS, Lewiecki EM, Tanner B, Randall S and Lindsay R; National Osteoporosis Foundation: Clinician's guide to prevention and treatment of osteoporosis. Osteoporos Int 25: 2359-2381, 2014.

13. Nuti R, Brandi ML, Checchia G, Di Munno O, Dominguez L, Falaschi P, Fiore CE, Iolascon G, Maggi S, Michieli R, et al: Guidelines for the management of osteoporosis and fragility fractures. Intern Emerg Med 14: 85-102, 2019.

14. Marshall D, Johnell O and Wedel H: Meta-analysis of how well measures of bone mineral density predict occurrence of osteoporotic fractures. BMJ 312: 1254-1259, 1996.

15. Szulc P and Delmas PD: Biochemical markers of bone turnover: Potential use in the investigation and management of postmenopausal osteoporosis. Osteoporos Int 19: 1683-1704, 2008.

16. Dempster D, Cauley J, Bouxsein M and Cosman F (eds.): Lessons from bone histomorphometry on the mechanisms of action of osteoporosis drugs. In: Marcus and Feldman's Osteoporosis. 5th edition. Academic Press, Cambridge, MA, USA, pp1835-1863, 2020 .

17. Schuiling KD, Robinia K and Nye R: Osteoporosis update J Midwifery Womens Health 56: 615-627, 2011.

18. Zmuda JM, Sheu YT and Moffett SP: The search for human osteoporosis genes. J Musculoskelet Neuronal Interact 6: 3-15, 2006.

19. Sadler C and Huff M: African-American women: Health beliefs, lifestyle, and osteoporosis. Orthop Nurs 26: 96-101, 2007.

20. Kanis JA, Burlet N, Cooper C, Delmas PD, Reginster JY Borgstrom F and Rizzoli R; European Society for Clinical and Economic Aspects of Osteoporosis and Osteoarthritis (ESCEO): European guidance for the diagnosis and management of osteoporosis in postmenopausal women. Osteoporos Int 19: 399-428, 2008.

21. Kuo TR and Chen CH: Bone biomarker for the clinical assessment of osteoporosis: Recent developments and future perspectives. Biomark Res 5: 18, 2017.

22. Qaseem A, Snow V, Shekelle P, Hopkins R Jr, Forciea MA and Owens DK; Clinical Efficacy Assessment Subcommittee of the American College of Physicians: Pharmacologic treatment of low bone density or osteoporosis to prevent fractures: A clinical practice guideline from the American college of physicians. Ann Intern Med 149: 404-415, 2008.

23. Wada $\mathrm{T}$, Nakashima T, Hiroshi $\mathrm{N}$ and Penninger JM: RANKL-RANK signaling in osteoclastogenesis and bone disease. Trends Mol Med 12: 17-25, 2006.

24. Boyle WJ, Simonet WS and Lacey DL: Osteoclast differentiation and activation. Nature 423: 337-342, 2003.

25. Li H, Xiao Z, Quarles LD and Li W: Osteoporosis: Mechanism, molecular target and current status on drug development. Curr Med Chem 28: 1489-1507, 2021.

26. Yasuda H, Shima N, Nakagawa N, Yamaguchi K, Kinosaki M, Mochizuki S, Tomoyasu A, Yano K, Goto M, Murakami A, et al: Osteoclast differentiation factor is a ligand for osteoprotegerin/osteoclastogenesis-inhibitory factor and is identical to TRANCE/RANKL. Proc Natl Acad Sci USA 95: 3597-3602, 1998.

27. Wong BR, Rho J, Arron J, Robinson E, Orlinick J, Chao M, Kalachikov S, Cayani E, Bartlett FS III, Frankel WN, et al: TRANCE is a novel ligand of the tumor necrosis factor receptor family that activates c-Jun N-terminal kinase in T cells. J Biol Chem 272: 25190-25194, 1997.

28. Park JH, Lee NK and Lee SY: Current understanding of RANK signaling in osteoclast differentiation and maturation. Mol Cells 40: 706-713, 2017

29. Xu F and Teitelbaum SL: Osteoclasts: New insights. Bone Res 1: $11-26,2013$

30. Yamashita T, Takahashi $\mathrm{N}$ and Udagawa N: New roles of osteoblasts involved in osteoclast differentiation. World J Orthop 3 : 175-181, 2012.

31. Rucci N: Molecular biology of bone remodelling. Clin Cases Miner Bone Metab 5: 49-56, 2008.

32. Teitelbaum SL: Bone resorption by osteoclasts. Science 289 : 1504-1508, 2000.

33. Hienz SA, Paliwal S and Ivanovski S: Mechanisms of bone resorption in periodontitis. J Immunol Res 2015: 615486, 2015.

34. Das S and Crockett JC: Osteoporosis-a current view of pharmacological prevention and treatment. Drug Des Devel Ther 7: 435-448, 2013

35. Henriksen K, Bollerslev J, Everts V and Karsdal MA: Osteoclast activity and subtypes as a function of physiology and pathology-implications for future treatments of osteoporosis. Endocr Rev 32: 31-63, 2011.
36. Arnett T: Regulation of bone cell function by acid-base balance. Proc Nutr Soc 62: 511-520, 2003.

37. Blair HC,Zaidi M, Huang CL and Sun L: The developmental basis of skeletal cell differentiation and the molecular basis of major skeletal defects. Biol Rev Camb Philos Soc 83: 401-415, 2008.

38. Pittenger MF, Mackay AM, Beck SC, Jaiswal RK, Douglas R, Mosca JD, Moorman MA, Simonetti DW, Craig S and Marshak DR: Multilineage potential of adult human mesenchymal stem cells. Science 284: 143-147, 1999.

39. Nakashima K and de Crombrugghe B: Transcriptional mechanisms in osteoblast differentiation and bone formation. Trends Genet 19: 458-466, 2003.

40. Brighton CT and Hunt RM: Histochemical localization of calcium in the fracture callus with potassium pyroantimonate. Possible role of chondrocyte mitochondrial calcium in callus calcification. J Bone Joint Surg Am 68: 703-715, 1986.

41. de Crombrugghe B, Lefebvre V and Nakashima K: Regulatory mechanisms in the pathways of cartilage and bone formation. Curr Opin Cell Biol 13: 721-727, 2001

42. Brighton CT and Hunt RM: Early histological and ultrastructural changes in medullary fracture callus. J Bone Joint Surg Am 73: 832-847, 1991.

43. Soltanoff CS, Yang S, Chen W and Li YP: Signaling networks that control the lineage commitment and differentiation of bone cells. Crit Rev Eukaryot Gene Expr 19, 2009.

44. Chau JF, Leong WF and Li B: Signaling pathways governing osteoblast proliferation, differentiation and function. Histol Histopathol 24: 1593-1606, 2009.

45. Meyer MB, Benkusky NA and Pike JW: The RUNX2 cistrome in osteoblasts: Characterization, down-regulation following differentiation, and relationship to gene expression. J Biol Chem 289: 16016-16031, 2014.

46. Lin GL and Hankenson KD: Integration of BMP, Wnt, and notch signaling pathways in osteoblast differentiation. J Cell Biochem 112: 3491-3501, 2011

47. Burch J, Rice S, Yang H, Neilson A, Stirk L, Francis R, Holloway P, Selby P and Craig D: Systematic review of the use of bone turnover markers for monitoring the response to osteoporosis treatment: The secondary prevention of fractures, and primary prevention of fractures in high-risk groups. Health Technol Assess 18: 1-180, 2014.

48. Mori G, D'Amelio P, Faccio R and Brunetti G: The interplay between the bone and the immune system. Clin Dev Immunol 2013: 720504, 2013

49. Lacey DL, Boyle WJ, Simonet WS, Kostenuik PJ, Dougall WC Sullivan JK, San Martin J and Dansey R: Bench to bedside: Elucidation of the OPG-RANK-RANKL pathway and the development of denosumab. Nat Rev Drug Discov 11: 401-419, 2012.

50. Noble BS: The osteocyte lineage. Arch Biochem Biophys 473 106-111, 2008

51. Klein-Nulend J, Nijweide PJ and Burger EH: Osteocyte and bone structure. Curr Osteoporos Rep 1: 5-10, 2003.

52. Rochefort GY: The osteocyte as a therapeutic target in the treatment of osteoporosis. Ther Adv Musculoskelet Dis 6: 79-91, 2014

53. Bonewald LF: The amazing osteocyte. J Bone Miner Res 26 229-238, 2011.

54. Nakashima T, Hayashi M, Fukunaga T, Kurata K, Oh-Hora M, Feng JQ, Bonewald LF, Kodama T, Wutz A, Wagner EF, et al: Evidence for osteocyte regulation of bone homeostasis through RANKL expression. Nat Med 17: 1231-1234, 2011.

55. Goldring SR: The osteocyte: Key player in regulating bone turnover. RMD Open 1 (Suppl 1): e000049, 2015.

56. Moriishi T, Fukuyama R, Ito M, Miyazaki T, Maeno T, Kawai Y, Komori $\mathrm{H}$ and Komori T: Osteocyte network; a negative regulatory system for bone mass augmented by the induction of Rankl in osteoblasts and Sost in osteocytes at unloading. PLoS One 7: e40143, 2012.

57. Kramer I, Halleux C, Keller H, Pegurri M, Gooi JH, Weber PB, Feng JQ, Bonewald LF and Kneissel M: Osteocyte $\mathrm{Wnt} /$ beta-catenin signaling is required for normal bone homeostasis. Mol Cell Biol 30: 3071-3085, 2010.

58. Bellido T: Osteocyte apoptosis induces bone resorption and impairs the skeletal response to weightlessness. IBMS BoneKEy 4: 252, 2007.

59. Chamoux E, Houde N, L'eriger K and Roux S: Osteoprotegerin decreases human osteoclast apoptosis by inhibiting the TRAIL pathway. J Cell Physiol 216: 536-542, 2008.

60. Yen ML, Hsu PN, Liao HJ, Lee BH and Tsai HF: TRAF-6 dependent signaling pathway is essential for TNF-related apoptosis-inducing ligand (TRAIL) induces osteoclast differentiation. PLoS One 7: e38048, 2012. 
61. Bikle DD: Vitamin D metabolism, mechanism of action, and clinical applications. Chem Biol 21: 319-329, 2014.

62. Norman AW: From vitamin D to hormone D: Fundamentals of the vitamin D endocrine system essential for good health. Am J Clin Nutr 88: 491S-499S, 2008.

63. Valero Zanuy M and Hawkins Carranza F: Metabolism, endogenous and exogenous sources of vitamin D. Rev Esp Enferm Metab Oseas 16: 63-70, 2007.

64. Silva MC and Furlanetto TW: Intestinal absorption of vitamin D: A systematic review. Nutr Rev 76: 60-76, 2018.

65. Compston JE, Merrett AL, Hammett FG and Magill P: Comparison of the appearance of radiolabelled vitamin D3 and 25-hydroxy-vitamin D3 in the chylomicron fraction of plasma after oral administration in man. Clin Sci (Lond) 60: 241-243, 1981.

66. Gil A, Plaza-Diaz J and Mesa MD: Vitamin D: Classic and novel actions. Ann Nutr Metab 72: 87-95, 2018.

67. Naveh-Many T, Marx R, Keshet E, Pike JW and Silver J: Regulation of 1,25-dihydroxyvitamin D3 receptor gene expression by 1,25 -dihydroxyvitamin D3 in the parathyroid in vivo. J Clin Invest 86: 1968-1975, 1990.

68. Glendenning P, Ratajczak T, Dick IM and Prince RL: Calcitriol upregulates expression and activity of the $1 \mathrm{~b}$ isoform of the plasma membrane calcium pump in immortalized distal kidney tubular cells. Arch Biochem Biophys 380: 126-132, 2000.

69. Kuchuk NO, van Schoor NM, Pluijm SM, Chines A and Lips P Vitamin D status, parathyroid function, bone turnover, and BMD in postmenopausal women with osteoporosis: Global perspective. J Bone Miner Res 24: 693-701, 2009.

70. Harada S, Mizoguchi T, Kobayashi Y, Nakamichi Y, Takeda S Sakai S, Takahashi F, Saito H, Yasuda H, Udagawa N, et al: Daily administration of eldecalcitol (ED-71), an active vitamin D analog, increases bone mineral density by suppressing RANKL expression in mouse trabecular bone. J Bone Miner Res 27: 461-473, 2012.

71. Takeda S, Yoshizawa T, Nagai Y, Yamato H, Fukumoto S Sekine K, Kato S, Matsumoto T and Fujita T: Stimulation of osteoclast formation by 1,25 -dihydroxyvitamin $\mathrm{D}$ requires its binding to vitamin D receptor (VDR) in osteoblastic cells: studies using VDR knockout mice. Endocrinology 140 : 1005-1008, 1999.

72. Christakos S, Dhawan P, Verstuyf A, Verlinden L and Carmeliet G: Vitamin D: Metabolism, molecular mechanism of action, and pleiotropic effects. Physiol Rev 96: 365-408, 2016.

73. Kim S, Yamazaki M, Zella LA, Shevde NK and Pike JW: Activation of receptor activator of NF-kappaB ligand gene expression by 1,25 -dihydroxyvitamin D3 is mediated through multiple long-range enhancers. Mol Cell Biol 26: 6469-6486, 2006.

74. Ukon Y, Makino T, Kodama J, Tsukazaki H, Tateiwa D, Yoshikawa $\mathrm{H}$ and Kaito T: Molecular-based treatment strategies for osteoporosis: A literature review. Int J Mol Sci 20: 2557, 2019

75. Watts NB, Bilezikian JP, Camacho PM, Greenspan SL, Harris ST, Hodgson SF, Kleerekoper M, Luckey MM, McClung MR, Pollack RP, et al: American association of clinical endocrinologists medical guidelines for clinical practice for the diagnosis and treatment of postmenopausal osteoporosis. Endocr Pract 16 (Suppl 3): S1-S37, 2010.

76. Kim SY, Zhang M and Bockman R: Bone mineral density response from teriparatide in patients with osteoporosis. HSS J 13: 171-177, 2017.

77. Estell EG and Rosen CJ: Emerging insights into the comparative effectiveness of anabolic therapies for osteoporosis. Nat Rev Endocrinol 17: 31-46, 2021.

78. Pavone V, Testa G, Giardina SMC, Vescio A, Restivo DA and Sessa G: Pharmacological therapy of osteoporosis: A systematic current review of literature. Front Pharmacol 8: 803, 2017.

79. North American Menopause Societ: Management of osteoporosis in postmenopausal women: 2006 position statement of The North American menopause society. Menopause 13: 340-367; quiz $368-9,2006$

80. Drake MT, Clarke BL and Khosla S: Bisphosphonates: mechanism of action and role in clinical practice. Mayo Clin Proc 83: 1032-1045, 2008.

81. Colucci S, Minielli V, Zambonin G, Cirulli N, Mori G, Serra M, Patella V, Zambonin Zallone A and Grano M: Alendronate reduces adhesion of human osteoclast-like cells to bone and bone protein-coated surfaces. Calcif Tissue Int 63: 230-235, 1998.

82. Sato M, Grasser W, Endo N, Akins R, Simmons H, Thompson DD, Golub E and Rodan GA: Bisphosphonate action. Alendronate localization in rat bone and effects on osteoclast ultrastructure. J Clin Invest 88: 2095-2105, 1991.
83. Papapoulos SE: Bisphosphonates: How do they work? Best Pract Res Clin Endocrinol Metab 22: 831-847, 2008

84. Russell RG: Bisphosphonates: The first 40 years. Bone 49: 2-19, 2011

85. Barnsley J, Buckland G, Chan PE, Ong A, Ramos AS, Baxter M, Laskou F, Dennison EM, Cooper C and Patel HP: Pathophysiology and treatment of osteoporosis: Challenges for clinical practice in older people. Aging Clin Exp Res 33: 759-773, 2021

86. Garg MK and Kharb S: Dual energy X-ray absorptiometry: Pitfalls in measurement and interpretation of bone mineral density. Indian J Endocrinol Metab 17: 203-210, 2013

87. Rogers MJ: From molds and macrophages to mevalonate: A decade of progress in understanding the molecular mode of action of bisphosphonates. Calcif Tissue Int 75: 451-461, 2004

88. Russell RG: Bisphosphonates: Mode of action and pharmacology. Pediatrics 119 (Suppl 2): S150-S162, 2007.

89. Dunford JE: Molecular targets of the nitrogen containing bisphosphonates: The molecular pharmacology of prenyl synthase inhibition. Curr Pharm Des 16: 2961-2969, 2010.

90. Kanis JA, Cooper C, Rizzoli R and Reginster JY; Scientific Advisory Board of the European Society for Clinical and Economic Aspects of Osteoporosis (ESCEO) and the Committees of Scientific Advisors and National Societies of the International Osteoporosis Foundation (IOF): European guidance for the diagnosis and management of osteoporosis in postmenopausal women. Osteoporos Int 30: 3-44, 2019.

91. Simon JA: Are all bisphosphonates the same? Potential reasons for clinical differences: A perspective. J Womens Health (Larchmt) 19: 719-727, 2010

92. Qaseem A, Forciea MA, McLean RM, Denberg TD; Clinical Guidelines Committee of the American College of Physicians, Barry MJ, Cooke M, Fitterman N, Harris RP, Humphrey LL, et al: Treatment of low bone density or osteoporosis to prevent fractures in men and women: A clinical practice guideline update from the American College of Physicians. Ann Intern Med 166: 818-839, 2017.

93. Nelson HD, Haney EM, Dana T, Bougatsos C and Chou R: Screening for osteoporosis: An update for the US preventive services task force. Ann Intern Med 153: 99-111, 2010.

94. Park-Wyllie LY, Mamdani MM, Juurlink DN, Hawker GA, Gunraj N, Austin PC, Whelan DB, Weiler PJ and Laupacis A: Bisphosphonate use and the risk of subtrochanteric or femoral shaft fractures in older women. JAMA 305: 783-789, 2011.

95. Rossini M, Adami S, Bertoldo F, Diacinti D, Gatti D, Giannini S, Giusti A, Malavolta N, Minisola S, Osella G, et al: Guidelines for the diagnosis, prevention and management of osteoporosis. Reumatismo 68: 1-39, 2016.

96. Pazianas $\mathrm{M}$ and Abrahamsen B: Osteoporosis treatment: Bisphosphonates reign to continue for a few more years, at least? Ann N Y Acad Sci 1376: 5-13, 2016.

97. Lorentzon M: Treating osteoporosis to prevent fractures: Current concepts and future developments. J Intern Med 285 381-394, 2019

98. Tsourdi E, Langdahl B, Cohen-Solal M, Aubry-Rozier B, Eriksen EF, Guañabens N, Obermayer-Pietsch B, Ralston SH, Eastell R and Zillikens MC: Discontinuation of denosumab therapy for osteoporosis: A systematic review and position statement by ECTS. Bone 105: 11-17, 2017.

99. Takeuchi T, Tanaka Y, Ishiguro N, Yamanaka H, Yoneda T, Ohira T, Okubo N, Genant HK and van der Heijde D: Effect of denosumab on Japanese patients with rheumatoid arthritis: A dose-response study of AMG 162 (Denosumab) in patients with RheumatoId arthritis on methotrexate to Validate inhibitory effect on bone Erosion (DRIVE)-a 12-month, multicentre, randomised, double-blind, placebo-controlled, phase II clinical trial. Ann Rheum Dis 75: 983-990, 2016.

100. Bone HG, Wagman RB, Brandi ML, Brown JP, Chapurlat R, Cummings SR, Czerwiński E, Fahrleitner-Pammer A, Kendler DL, Lippuner K, et al: 10 years of denosumab treatment in postmenopausal women with osteoporosis: Results from the phase 3 randomised FREEDOM trial and open-label extension. Lancet Diabetes Endocrinol 5: 513-523, 2017.

101. Tabatabaei-Malazy O, Salari P, Khashayar P and Larijani B: New horizons in treatment of osteoporosis. DARU 25: 2, 2017.

102. Bonani M, Frey D, de Rougemont O, Mueller NJ, Mueller TF, Graf $\mathrm{N}$ and Wüthrich RP: Infections in de novo kidney transplant recipients treated with the RANKL inhibitor denosumab. Transplantation 101: 2139-2145, 2017. 
103. Cummings SR, Ferrari S, Eastell R, Gilchrist N, Jensen JB, McClung M, Roux C, Törring O, Valter I, Wang AT and Brown JP Vertebral fractures after discontinuation of denosumab: A post hoc analysis of the randomized placebo-controlled FREEDOM trial and its extension. J Bone Miner Res 33: 190-198, 2018.

104. Krum SA and Brown M: Unraveling estrogen action in osteoporosis. Cell Cycle 7: 1348-1352, 2008.

105. Kanis JA, McCloskey EV, Johansson H, Cooper C, Rizzoli R and Reginster JY; Scientific Advisory Board of the European Society for Clinical and Economic Aspects of Osteoporosis and Osteoarthritis (ESCEO) and the Committee of Scientific Advisors of the International Osteoporosis Foundation (IOF): European guidance for the diagnosis and management of osteoporosis in postmenopausal women. Osteoporos Int 24: 23-57, 2013.

106. Lobo RA, Pickar JH, Stevenson JC, Mack WJ and Hodis HN: Back to the future: Hormone replacement therapy as part of a prevention strategy for women at the onset of menopause. Atherosclerosis 254: 282-290, 2016.

107. Cartwright B, Robinson J, Seed PT, Fogelman I and Rymer J: Hormone replacement therapy versus the combined ora contraceptive pill in premature ovarian failure: A randomized controlled trial of the effects on bone mineral density. J Clin Endocrinol Metab 101: 3497-3505, 2016.

108. Rossouw JE, Anderson GL, Prentice RL, LaCroix AZ, Kooperberg C, Stefanick ML, Jackson RD, Beresford SA, Howard BV, Johnson KC, et al: Risks and benefits of estrogen plus progestin in healthy postmenopausal women: Principal results from the Women's Health Initiative randomized controlled trial. JAMA 288: 321-333, 2002.

109. Maximov PY, Lee TM and Jordan VC: The discovery and development of selective estrogen receptor modulators (SERMs) for clinical practice. Curr Clin Pharmacol 8: 135-155, 2013.

110. Siddiqui JA and Partridge NC: Physiological bone remodeling: Systemic regulation and growth factor involvement Physiology (Bethesda) 31: 233-245, 2016.

111. Gooi JH, Pompolo S, Karsdal MA, Kulkarni NH, Kalajzic I, McAhren SH, Han B, Onyia JE, Ho PW, Gillespie MT, et al Calcitonin impairs the anabolic effect of PTH in young rats and stimulates expression of sclerostin by osteocytes. Bone 46 1486-1497, 2010.

112. Keller J, Catala-Lehnen P, Huebner AK, Jeschke A, Heckt T, Lueth A, Krause M, Koehne T, Albers J, Schulze J, et al Calcitonin controls bone formation by inhibiting the release of sphingosine 1-phosphate from osteoclasts. Nat Commun 5 $5215,2014$.

113. Bandeira L,Lewiecki EM and Bilezikian JP: Pharmacodynamics and pharmacokinetics of oral salmon calcitonin in the treatment of osteoporosis. Expert Opin Drug Metab Toxicol 12: 681-689, 2016

114. Drake MT, Clarke BL, Oursler MJ and Khosla S: Cathepsin K inhibitors for osteoporosis: Biology, potential clinical utility, and lessons learned. Endocr Rev 38: 325-350, 2017.

115. Dai R, Wu Z, Chu HY, Lu J, Lyu A, Liu J and Zhang G: Cathepsin K: The action in and beyond bone. Front Cell Dev Biol 8: 433, 2020.

116. Takito J, Inoue S and Nakamura M: The sealing zone in osteoclasts: A self-organized structure on the bone. Int J Mol Sci 19: 984, 2018.

117. Fonović M and Turk B: Cysteine cathepsins and extracellular matrix degradation. Biochim Biophys Acta 1840: 2560-2570, 2014

118. Mullard A: Merck \& Co. drops osteoporosis drug odanacatib. Nat Rev Drug Discov 15: 669, 2016.

119. Brömme D and Lecaille F: Cathepsin K inhibitors for osteoporosis and potential off-target effects. Expert Opin Investig Drugs 18: 585-600, 2009.

120. Eastell R, Nagase S, Ohyama M, Small M, Sawyer J, Boonen S, Spector T, Kuwayama T and Deacon S: Safety and efficacy of the cathepsin $\mathrm{K}$ inhibitor ONO-5334 in postmenopausal osteoporosis: The OCEAN study. J Bone Miner Res 26: 1303-1312, 2011.

121. Stoch SA,Zajic S, Stone JA, Miller DL, van Bortel L, Lasseter KC, Pramanik B, Cilissen C, Liu Q, Liu L, et al: Odanacatib, a selective cathepsin $\mathrm{K}$ inhibitor to treat osteoporosis: safety, tolerability, pharmacokinetics and pharmacodynamics-results from single oral dose studies in healthy volunteers. Br J Clin Pharmacol 75: 1240-1254, 2013.

122. Khan B, Ahmed Z and Ahmad W: A novel missense mutation in cathepsin K (CTSK) gene in a consanguineous Pakistani family with pycnodysostosis. J Investig Med 58: 720-724, 2010.
123. Iñiguez-Ariza NM and Clarke BL: Bone biology, signaling pathways, and therapeutic targets for osteoporosis. Maturitas 82 245-255, 2015

124. Chapurlat RD: Odanacatib: A review of its potential in the management of osteoporosis in postmenopausal women. Ther Adv Musculoskelet Dis 7: 103-109, 2015.

125. Marie PJ: The calcium-sensing receptor in bone cells: A potential therapeutic target in osteoporosis. Bone 46: 571-576, 2010.

126. Spector TD, Calomme MR, Anderson SH, Clement G, Bevan L, Demeester N, Swaminathan R, Jugdaohsingh R, Berghe DA and Powell JJ: Choline-stabilized orthosilicic acid supplementation as an adjunct to calcium/vitamin D3 stimulates markers of bone formation in osteopenic females: A randomized, placebo-controlled trial. BMC Musculoskelet Disord 9: 85, 2008.

127. Hamdy NA: Strontium ranelate improves bone microarchitecture in osteoporosis. Rheumatology (Oxford) 48 (Suppl 4) iv9-iv13, 2009.

128. Pilmane M, Salma-Ancane K, Loca D, Locs J and Berzina-Cimdina L: Strontium and strontium ranelate: Historical review of some of their functions. Mater Sci Eng C Mater Biol Appl 78: 1222-1230, 2017.

129. Delany AM, Amling M, Priemel M, Howe C, Baron R and Canalis E: Osteopenia and decreased bone formation in osteonectin-deficient mice. J Clin Invest 105: 915-923, 2000

130. Kanis JA, Johansson H, Oden A and McCloskey EV: A meta-analysis of the effect of strontium ranelate on the risk of vertebral and non-vertebral fracture in postmenopausal osteoporosis and the interaction with FRAX®. Osteoporos Int 22: 2347-2355, 2011

131. Bolland MJ and Grey A: A comparison of adverse event and fracture efficacy data for strontium ranelate in regulatory documents and the publication record. BMJ Open 4: e005787, 2014.

132. Mi B, Xiong W, Xu N, Guan H, Fang Z, Liao H, Zhang Y, Gao B, Xiao X, Fu J and Li F: Strontium-loaded titania nanotube arrays repress osteoclast differentiation through multiple signalling pathways: In vitro and in vivo studies. Sci Rep 7: 2328, 2017.

133. Gupta S, Termini JM, Kanagavelu S and Stone GW: Design of vaccine adjuvants incorporating TNF superfamily ligands and TNF superfamily molecular mimics. Immunol Res 57: 303-310, 2013.

134. Liu C, Walter TS, Huang P, Zhang S, Zhu X, Wu Y, Wedderburn LR, Tang P, Owens RJ, Stuart DI, et al: Structural and functional insights of RANKL-RANK interaction and signaling. J Immunol 184: 6910-6919, 2010.

135. Ko YJ, Sohn HM, Jang Y, Park M, Kim B, Kim B, Park JI, Hyun H, Jeong B, Hong C and Lim W: A novel modified RANKL variant can prevent osteoporosis by acting as a vaccine and an inhibitor. Clin Transl Med 11: e368, 2021.

136. Jang Y, Sohn HM, Ko YJ, Hyun H and Lim W: Inhibition of RANKL-Induced Osteoclastogenesis by Novel Mutant RANKL. Int J Mol Sci 22: 434, 2021.

137. Liu C, Zhao Y, He W, Wang W, Chen Y, Zhang S, Ma Y, Gohda J, Ishida T, Walter TS, et al: A RANKL mutant used as an inter-species vaccine for efficient immunotherapy of osteoporosis. Sci Rep 5: 14150, 2015

138. Wu T, Li F, Sha X, Li F, Zhang B, Ma W, Liu M, Yang W, Li H and Tao H: A novel recombinant RANKL vaccine prepared by incorporation of an unnatural amino acid into RANKL and its preventive effect in a murine model of collagen-induced arthritis. Int Immunopharmacol 64: 326-332, 2018.

139. Ling L, Hu HL, Liu KY, Ram YI, Gao JL and Cao YM: Long noncoding RNA MIRG induces osteoclastogenesis and bone resorption in osteoporosis through negative regulation of miR-1897. Eur Rev Med Pharmacol Sci 23: 10195-10203, 2019.

140. Wu QY,Li X, Miao ZN, Ye JX, Wang B,Zhang F, Xu RS, Jiang DL, Zhao MD and Yuan FL: Long Non-coding RNAs: A new regulatory code for osteoporosis. Front Endocrinol (Lausanne) 9 : 587, 2018.

141. Zhu J, Yu W, Wang Y, Xia K, Huang Y, Xu A, Chen Q, Liu B, Tao $\mathrm{H}, \mathrm{Li} \mathrm{F}$ and Liang C: lncRNAs: function and mechanism in cartilage development, degeneration, and regeneration. Stem Cell Res Ther 10: 344, 2019.

142. Wijnen WJ, Pinto YM and Creemers EE: The therapeutic potential of miRNAs in cardiac fibrosis: Where do we stand? J Cardiovasc Transl Res 6: 899-908, 2013.

143. Mandourah AY, Ranganath L, Barraclough R, Vinjamuri S, Hof RV, Hamill S, Czanner G, Dera AA, Wang D and Barraclough DL: Circulating microRNAs as potential diagnostic biomarkers for osteoporosis. Sci Rep 8: 8421, 2018. 
144. Rachner TD, Hofbauer LC, Göbel A and Tsourdi E: Novel therapies in osteoporosis: PTH-related peptide analogs and inhibitors of sclerostin. J Mol Endocrinol 62: R145-R154, 2019.

145. Borba VZ and Mañas NC: The use of PTH in the treatment of osteoporosis. Arq Bras Endocrinol Metabol 54: 213-219, 2010

146. Silva BC and Bilezikian JP: Parathyroid hormone: Anabolic and catabolic actions on the skeleton. Curr Opin Pharmacol 22: 41-50, 2015.

147. Gardella T: Interactions of PTH with Receptors and Signaling. The Parathyroids: Basic and Clinical Concepts. Third ed. Elsevier Inc: 65-80, 2015.

148. Datta NS and Abou-Samra AB: PTH and PTHrP signaling in osteoblasts. Cell Signal 21(8): 1245-1254. 2009.

149. Migliaccio S, Brama M and Malavolta N: Management of glucocorticoids-induced osteoporosis: Role of teriparatide. Ther Clin Risk Manag 5: 305-310, 2009.

150. Recker RR, Marin F, Ish-Shalom S, Möricke R, Hawkins F, Kapetanos G, de la Peña MP, Kekow J, Farrerons J, Sanz B, et al: Comparative effects of teriparatide and strontium ranelate on bone biopsies and biochemical markers of bone turnover in postmenopausal women with osteoporosis. J Bone Miner Res 24: 1358-1368, 2009.

151. Rubin MR and Bilezikian JP: New anabolic therapies in osteoporosis. Endocrinol Metab Clin North Am 32: 285-307, 2003.

152. Glover SJ, Eastell R, McCloskey EV, Rogers A, Garnero P, Lowery J, Belleli R, Wright TM and John MR: Rapid and robust response of biochemical markers of bone formation to teriparatide therapy. Bone 45: 1053-1058, 2009.

153. Cosman F: Abaloparatide: A new anabolic therapy on the horizon. Bonekey Rep 4: 661, 2015.

154. Neer RM, Arnaud CD, Zanchetta JR, Prince R, Gaich GA, Reginster JY, Hodsman AB, Eriksen EF, Ish-Shalom S, Genan HK, et al: Effect of parathyroid hormone (1-34) on fractures and bone mineral density in postmenopausal women with osteoporosis. N Engl J Med 344: 1434-1441, 2001.

155. Fukumoto $\mathrm{S}$ and Matsumoto T: Recent advances in the management of osteoporosis. F1000Research 6: 625, 2017.

156. Cheloha RW, Gellman SH, Vilardaga JP and Gardella TJ: PTH receptor-1 signalling-mechanistic insights and therapeutic prospects. Nat Rev Endocrinol 11: 712-724, 2015.

157. Hattersley G, Dean T, Corbin BA, Bahar H and Gardella TJ: Binding selectivity of abaloparatide for PTH-type-1-receptor conformations and effects on downstream signaling. Endocrinology 157: 141-149, 2016.

158. Boyce EG, Mai Y and Pham C: Abaloparatide: Review of a next-generation parathyroid hormone agonist. Ann Pharmacother 52: 462-472, 2018.

159. Gensure RC, Gardella TJ and Jüppner H: Parathyroid hormone and parathyroid hormone-related peptide, and their receptors. Biochem Biophys Res Commun 328: 666-678, 2005.

160. Wysolmerski JJ: Parathyroid hormone-related protein: An update. J Clin Endocrinol Metab 97: 2947-2956, 2012.

161. Iolascon G, Moretti A, Toro G, Gimigliano F, Liguori S and Paoletta M: Pharmacological therapy of osteoporosis: What's new? Clin Interv Aging 15: 485-491, 2020.

162. Pietrzyk B, Smertka M and Chudek J: Sclerostin: Intracellular mechanisms of action and its role in the pathogenesis of skeletal and vascular disorders. Adv Clin Exp Med 26: 1283-1291, 2017.

163. Lerner UH and Ohlsson C: The WNT system: background and its role in bone. J Intern Med 277: 630-649, 2015.
164. Li X, Zhang Y, Kang H, Liu W, Liu P, Zhang J, Harris SE and Wu D: Sclerostin binds to LRP5/6 and antagonizes canonical Wnt signaling. J Biol Chem 280: 19883-19887, 2005.

165. Cosman F, Crittenden DB, Adachi JD, Binkley N, Czerwinski E, Ferrari S, Hofbauer LC, Lau E, Lewiecki EM, Miyauchi A, et al: Romosozumab treatment in postmenopausal women with osteoporosis. N Engl J Med 375: 1532-1543, 2016.

166. Canalis E: Management of endocrine disease: Novel anabolic treatments for osteoporosis. Eur J Endocrinol 178: R33-R44, 2018.

167. Black DM, Greenspan SL, Ensrud KE, Palermo L, McGowan JA, Lang TF, Garnero P, Bouxsein ML, Bilezikian JP and Rosen CJ; PaTH Study Investigators: The effects of parathyroid hormone and alendronate alone or in combination in postmenopausal osteoporosis. N Engl J Med 349: 1207-1215, 2003

168. Lou S, Lv H, Yin P, Li Z, Tang P and Wang Y: Combination therapy with parathyroid hormone analogs and antiresorptive agents for osteoporosis: A systematic review and meta-analysis of randomized controlled trials. Osteoporos Int 30: 59-70, 2019.

169. Leder BZ, Tsai JN, Uihlein AV, Burnett-Bowie SA, Zhu Y, Foley K, Lee H and Neer RM: Two years of Denosumab and teriparatide administration in postmenopausal women with osteoporosis (The DATA Extension Study): A randomized controlled trial. J Clin Endocrinol Metab 99: 1694-1700, 2014.

170. Kitaguchi K, Kashii M, Ebina K, Kaito T, Okada R, Makino T, Noguchi T, Ishimoto T, Nakano T and Yoshikawa H: Effects of single or combination therapy of teriparatide and anti-RANKL monoclonal antibody on bone defect regeneration in mice. Bone 106: 1-10, 2018

171. Saag KG, Petersen J, Brandi ML, Karaplis AC, Lorentzon M, Thomas T, Maddox J, Fan M, Meisner PD and Grauer A: Romosozumab or alendronate for fracture prevention in women with osteoporosis. N Engl J Med 377: 1417-1427, 2017.

172. Langdahl BL, Libanati C, Crittenden DB, Bolognese MA, Brown JP, Daizadeh NS, Dokoupilova E, Engelke K, Finkelstein JS, Genant HK, et al: Romosozumab (sclerostin monoclonal antibody) versus teriparatide in postmenopausal women with osteoporosis transitioning from oral bisphosphonate therapy: A randomised, open-label, phase 3 trial. Lancet 390: 1585-1594, 2017.

173. Bone HG, Cosman F, Miller PD, Williams GC, Hattersley G, Hu MY, Fitzpatrick LA, Mitlak B, Papapoulos S, Rizzoli R, et al: ACTIVExtend: 24 months of alendronate after 18 months of abaloparatide or placebo for postmenopausal osteoporosis. J Clin Endocrinol Metab 103: 2949-2957, 2018.

174. Leder BZ, Tsai JN, Uihlein AV, Wallace PM, Lee H, Neer RM and Burnett-Bowie SA: Denosumab and teriparatide transitions in postmenopausal osteoporosis (the DATA-Switch study): Extension of a randomised controlled trial. Lancet 386: $1147-1155,2015$.

175. Bell NH and Johnson RH: Bisphosphonates in the treatment of osteoporosis. Endocrine 6: 203-206, 1997.

c) (i) (s) This work is licensed under a Creative Commons (c) ${ }_{\text {EY NC ND }}$ Attribution-NonCommercial-NoDerivatives 4.0 International (CC BY-NC-ND 4.0) License. 